\title{
Perspectives on the Current State of Foreign Trade Between the EU and Central Asia in a Period of Geoeconomic Change ${ }^{1}$
}

\author{
E. Kašt’áková, M. Žatko, N. Barinková
}

Elena Kaštáková - PhD, Associate Professor at the Department of International Trade, Faculty of Commerce, University of Economics in Bratislava, Dolnozemská cesta 1, 85235 Bratislava, Slovak Republic; E-mail: elena.kastakova@euba.sk

Matúš Žatko, PhD - Assistant Professor at the Department of International Trade, Faculty of Commerce, University of Economics in Bratislava, Dolnozemská cesta 1, 85235 Bratislava, Slovak Republic; E-mail: matus.zatko@euba.sk

Natália Barinková - PhD, Student at the Department of International Trade, Faculty of Commerce, University of Economics in Bratislava, Dolnozemská cesta 1, 85235 Bratislava, Slovak Republic; E-mail: natalia. barinkova@euba.sk

\begin{abstract}
The article examines the current foreign trade relations between the EU and Central Asia. Based on econometric analysis, it sets out possible perspectives for the further development of mutual trade relations in the time of geoeconomic changes. As one of the most important integration groupings in the world, the EU has a significant influence in promoting its foreign trade interests. Central Asia is a part of Asia consisting of several states that are members of different regional integration groupings with different priorities. The result of the research is an analysis of mutual foreign trade relations. Character and perspective of mutual trade relations is assessed by using of selected one-factor indicators (trade complementarity index and trade intensity index). With the help of time-series forecast model, the article also tries to estimate the future development of EU exports as well as EU imports in relation to Central Asian countries. While the EU imports from Central Asian countries are dominated by minerals and fuels in the long term, EU exports consist of more sophisticated and diversified production. This represents the potential for further development of the business relationships and growth of mutual trade. In the case of favourable circumstances, a continuing growth trend in trade can be expected, especially on the side on EU exports.
\end{abstract}

Key words: EU; Central Asia; foreign trade; Complementarity Trade Index; Trade Intensity Index; Timeseries prediction model

For citation: Kaštáková E., Žatko M., Barinková N. (2020). Perspectives on the Current State of Foreign Trade Between the EU and Central Asia in a Period of Geoeconomic Change. International Organisations Research Journal, vol. 16, no 1, pp. 145-161 (in English). DOI: 10.17323/1996-7845-2021-01-07

${ }^{1}$ This paper is a part of a research project of the Ministry of Education, Family and Sports of the Slovak Republic VEGA No. 1/0039/20 The Importance of the Eurasian Economic Union for Shaping of EU Trade Strategies (with Implications for Slovakia). 


\section{Introduction}

The current geopolitical situation is characterized by a high degree of volatility. Significant and often unexpected changes are occurring, affecting the players involved in international trade in a globalized economy [Puškárová, 2015]. As one of the most important integration groupings in the world, the European Union (EU) has a significant impact on the promotion of its foreign trade interests, but their implementation is difficult due to the changing geopolitical situation. These interests are specified in the document adopted by the European Commission in 2015 on the EU's trade and investment strategy [EC, 2019]. Geostrategic position and natural resources characterize the importance of Central Asia. In addition, the EU is an economic bridge to China. The importance of the Central Asian region will increase as a result of the construction of the New Silk Road project as a strategy for developing cooperation between the EU and Asia (China).

In the early 1990s, as the countries of Central Asia gained their independence, they made significant progress in building their national identities. In this context, it should be noted that after the collapse of the Soviet Union, these countries began the state-building process burdened with the challenges posed by neglected infrastructure, ecological devastation, very weak to non-existent interconnections with regional and global transport networks and markets and mostly non-existent state institutions. In light of these and other challenges, such as the existing security threats posed by the deteriorating situation in the Middle East, climate change, the current coronavirus pandemic, and also the growing geopolitical and geoeconomic impact of neighbouring countries such as China, Russia, Iran, Turkey and others, it is admirable that these countries continue to maintain the relative stability and security of the Central Asian region. The region can use its potential, to which we can assign energy resources, mineral wealth and a strategic position between Europe and Asia, as well as a high representation of young people, to create a suitable business and social environment that allows full cooperation with neighbouring countries. The European Union wants to be a stable and reliable partner for the countries of Central Asia in these processes.

While there are many definitions of Central Asia, the Great Soviet Encyclopedia's definition of the region as made up of Kazakhstan, Kyrgyzstan, Uzbekistan, Tajikistan and Turkmenistan [Prokhoro, 1975] is the most accepted and will be used in this article. The Central Asian region is an area of more than four million $\mathrm{km}^{2}$ and a population of 62 million. The World Bank characterizes Central Asia as a diverse region consisting of upper middle- and low-income countries of great strategic importance in view of their location and the availability of natural resources [World Bank, 2019]. The region's economies are developing differently, but countries are striving for closer economic cooperation. Economic cooperation between Kazakhstan and Kyrgyzstan is intensive as both countries are members of the Eurasian Economic Union, established in 2015 with the aim of broadening economic cooperation between its members, to promote regional economic cooperation, to ensure the free movement of goods, services and capital and to provide a common customs policy. In addition to Kazakhstan and Kyrgyzstan, Russia, Belarus and Armenia are members of the Union. The economic development of the whole region is now often mentioned in connection with the Chinese New Silk Road project. Its geographical location and untapped economic potential predetermine its strategic position as a crossroads of political and economic interests.

As economically and geopolitically promising countries, the EU is trying to strengthen political and economic relations with them. From a trade point of view, these countries are currently not among the EU's important trading partners. In recent years, however, the trend has been toward increasing development of trade relations, and the indices of trade intensity and 
trade complementarity show there is space for further trade growth. In this article, we examine the current state of the EU's foreign trade relations with Central Asia and determine possible areas for increased trade between them in a period of geoeconomic change on the basis of econometric analysis using selected one-factor indicators - the trade complementarity index (TCI) and the trade intensity index (TII).

\section{Literature Review}

Central Asia is a large inland region of Asia. There are several definitions of Central Asia, but none of them is generally accepted. Thus, the term Central Asia has no clear definition. In 1843, the term Central Asia was first defined by the German geographer Alexander von Humboldt as the distinct region of the world. Due to the geographical connections and cultural interrelations, his definition included Afghanistan and Western China. [Dani, Masson, 1992]. As defined by the 1975 Great Soviet Encyclopedia, the term Central Asia encompasses Uzbekistan, Tajikistan, Turkmenistan, Kyrgyzstan and South Kazakhstan [Prokhorov, 1975]. The broadest definition is presented by UNESCO, according to which Central Asia includes Uzbekistan, Turkmenistan, Tajikistan, Kyrgyzstan, Kazakhstan, Mongolia, western China and Tibet, north-eastern Iran, Afghanistan, western Pakistan and northern India [Dani, Masson, 1992]. In its publication, the Asian Development Bank defines Central Asia as a region consisting of five former Soviet republics and Azerbaijan [Ifzal, 2003].

Historically, the importance of Central Asia was due to its location on the silk road between China and the Middle East and Europe [Byrd et al., 2006]. After the Napoleonic Wars, the region became strategic for the two Great Powers - England and Russia. With the collapse of the Soviet Union, other countries began to seek influence in the region. In addition to their strategic location, the countries of Central Asia are rich in mineral resources such as oil, natural gas, gold and uranium, making them attractive to potential colonizers and now to other powers [Makarenko, 2009]. Minerals have become a major factor in their economic development and an instrument of their foreign policy [Teleuova, 2015].

At present, the Central Asian region plays an important role in the geopolitical relations of Russia, the U.S., China and other regional players such as Iran and Turkey [Gnidchenko, 2018]. Russia's interests in the region are diverse, ranging from access to minerals to preventing the region's independence movements from spreading [Iqbal, Afridi, 2017]. Russia seeks to strengthen its political influence through a military presence and by supporting Russian companies in the area. The independence of the Central Asian countries in the 1990s corresponded to the beginning of China's economic growth and its increased demand for commodities. China's main interests are in the fields of security, energy and economic cooperation. China is gradually strengthening its position not only in terms of purchasing energy sources but also as an investor in the region [Drieniková, 2018]. Goods from China pass through Central Asian countries through the New Silk Road project to the Middle East and the EU. In light of China's interests, the region, which had previously been of marginal interest only, is becoming one of China's main foreign policy priorities [Grieger, 2015] and has drawn attention to China's growing influence in the region. For the U.S., interest in Central Asia increased following the 2001 terrorist attacks. Iran focuses more on economic cooperation with the Central Asian republics and offers its territory as a transit area for transporting oil to Turkey and subsequently to the EU. Turkey is a country through which Central Asian products can reach European markets [Fida, 2018]. The EU is not a key player in the region and cannot compete with Russia or China on the concept of the use of military force, focusing instead on the implementation of democratic principles, the protection of human rights and the fight against poverty [Konopelko, 2016]. In 
the past, energy has been the main area of cooperation between the EU and Central Asia, and other areas are currently coming to the forefront [Cornell, Engvall, 2017].

The analysis of economic relations between the EU and Central Asia and their contractual framework point to the importance of modernizing and updating the EU's strategy toward Central Asia, on which the EU-Central Asia relations and cooperation is based. The countries of the Commonwealth of Independent States are important trade partners for the EU [Drieniková, 2018].

It is important for the potential of mutual foreign trade to look at the extent to which the total demand and supply of the examined countries or integration/regional groupings overlap. Such a view is provided by the TCI, which is based on the assumption that both countries or groups of countries can benefit from increased mutual trade. The TCI was introduced for the first time in 1982 by R. Garnaut and P. Drysdale [World Bank, 2016]. The index has been updated by several other statistics, and there are dozens of versions. Trade complementarity was also calculated by M. Michaely [1996] and is used in World Trade Organization (WTO) and International Monetary Fund (IMF) calculations as well as in this article [WTO, 2012].

Another important indicator for determining the potential of mutual foreign trade is the TII. The intensity of trade between countries depends on many factors, such as the size of the economies, the level of their development, the gross domestic product (GDP) structure, geographical location and distance related to transport costs or a different cultural and institutional sphere. Trade intensity was first defined by A.J. Brown [Brown, 1949] and later by K. Kojima [Kojina, 1964]. They defined trade intensity as bilateral trade between two countries in relation to total world trade and its share in it. I. Yamazawa [Yamazawa, 1971] applied the intensity model. On this basis, he evaluated factors affecting trade intensity.

Prediction of foreign trade using econometric time series models of Gretl software was conducted by several authors. V. Ružeková, Z. Kittová and D. Steinhauser [2020] used this model to quantify and qualify the impact of the institutional environment on the export performance of a country. On the basis of this model, P. Baláž, M. Královičová and D. Steinhauser [2020] assessed the growth potential of trade in services between the EU and China.

\section{Methodology}

The TII is used to assess whether the trade volumes between two countries are larger or smaller than what would be expected on the basis of their world trade position. It is defined as the share of one country's exports going to a partner divided by the share of world exports going to the partner [World Bank, 2010].

It is calculated as:

$$
T I I_{i j}=\frac{\left(x_{i j} / X_{i t}\right)}{\left(x_{w j} / X_{w t}\right)},
$$

where $x_{i j}$ - represents the value of exports from country $i$ to country $j ; X_{i t}$ - represents the value of total exports of country $i$ to the world; $x_{w j}$ - represents the value of total world exports to country $j ; X_{w t}$ - represents the total value of the world's exports.

TII values range from 0 to $+\infty$. If the index value is 1 , it means that the exporting country $i$ exports to country $j$ an exact ratio of exports, which is a matter importing county considering its share of world import. If the index value is higher than 1, the business flows between examined countries are on a higher level than would be expected in view of the world economy. This means that country $i$ exports to country $j$ in a ratio of more goods than to the rest of the world. It 
is thus an intense trade relationship. If the value is less than 1, the intensity of trade is at a level lower than would be expected [World Bank, 2013].

The $T C I$ is one of the methods of calculating trade complementarity and measures the extent to which two countries are "natural trading partners." The index shows the extent to which one country's total exports overlap with what another country imports. The advantage of the index is that it identifies sectors complementary to foreign trade regardless of whether trading takes place directly between the countries under comparison. However, the index does not take into account that some sectors are not suitable for trade. Following the formula by M. Michaely [Michaely, 1996] who applied it for the first time in 1996 [WTO, 2012]:

$$
c^{i j}=100\left[1-\sum \frac{\left|m_{k}^{i}-x_{k}^{j}\right|}{2}\right],
$$

where $x_{k}^{j}$ is the share of product $k$ in total exports of country $j$ and $m^{i}$ is the share of product $k$ in total imports of country $i$.

Value range: the index can range from 0 to 100. If $c^{i j}=100-$ countries are ideal trading partners; $c^{i j}=0-$ countries are ideal competitors that exactly match exports and imports.

TCI calculations are not recommended in some cases. Countries that are geographically distant or incur high transport and transaction costs may not be ideal trading partners despite the high values of the complementarity index.

To predict the future trade relations between the EU and Central Asian countries, we used a time series prediction model calculated on Gretl software. Based on existing values, the function calculates or estimates the future value of the dependent variable $y$ for a given value of the independent variable $\mathrm{x}$. Pairs of numbers $\mathrm{x}$ and $\mathrm{y}$ are known values of numbers. The function estimates the new value using linear regression [Lukáčik, Lukáčiková, Szomolányi, 2018]. The equation for calculating the function is:

$$
y=a+b x,
$$

where

$$
a=\bar{y}-b \bar{x}
$$

and

$$
b=\frac{\sum(x-\bar{x})(y-\bar{y})}{\sum(x-\bar{x})^{2}},
$$

where $x$ and $y$ are the mean values of the sample AVERAGE (known $x$ ) and AVERAGE (known $y$ ).

The function also determines the oscillation range of predicted values. In our forecast, we worked with a $95 \%$ range of probability limits.

For the purpose of this research, data was obtained from the European Commission, the EUROSTAT database and the United Nations Conference on Trade and Development database (UNCTADSTAT), which provide data for the analysis of foreign trade between Central Asia and the EU. The foreign trade commodity structure was classified according to the Standard International Trade Classification (SITC).

The limitation of the research is as follows: the analysis of the development of foreign trade between the EU and Central Asia has been determined from 2010 to 2019. In the case of using the econometric model of time series forecast, we used EU27 statistics, as the United Kingdom is not a member of the EU in 2020. 


\section{Results}

Central Asia is a strategically important region for the EU. According to A.-S. Gast [2014] there are three main reasons why the EU is strengthening its position toward the region and also consolidating it with a contractual basis: mineral resources, the geostrategic importance of the region and the pursuit of an expanded sphere of influence. J. Boonstra and R. Panella [Boonstra, Panella, 2017] claim that the Central Asian region is important to the EU, mainly because the EU is an alternative to Russia and China based on a value-based approach with stable economic development and the promotion of cooperation.

The EU seeks to develop relations with Central Asia as a whole but also with individual countries. EU-Central Asia relations were governed by the EU Central Asia Strategy, signed in 2007 and reviewed in 2015, focused in particular on promoting sustainable development principles and bilateral relations [Apokins, 2016]. In the field of trade and investment, the strategy also aimed to support the accession of Central Asian countries to the WTO. Currently, Uzbekistan remains only an observer country to the WTO and Turkmenistan has not yet applied to join. The EU has developed a new strategy taking into account the current geopolitical and economic situation. The High Representative of the Union for Foreign Affairs and Security Policy and the European Commission introduced a new strategy for Central Asia entitled The EU and Central Asia: New Opportunities for a Stronger Partnership. The strategy was adopted by the EU Council in June 2019 and focuses on areas such as water and environmental cooperation, socio-economic development, support for small and medium-sized enterprises (SMEs) and support for regional trade [Euractiv, 2019].

The EU's bilateral relations with Central Asian countries are governed by non-preferential partnership and cooperation agreements (PCAs) and enhanced partnership and cooperation agreements (EPCAs), shown in Table 1.

Table 1. EU Contractual Frameworks With Central Asian Countries

\begin{tabular}{|l|l|l|l|l|l|}
\hline & \multicolumn{1}{|c|}{ Kazakhstan } & \multicolumn{1}{|c|}{ Kyrgyzstan } & \multicolumn{1}{c|}{ Tajikistan } & \multicolumn{1}{c|}{ Turkmenistan } & \multicolumn{1}{c|}{ Uzbekistan } \\
\hline PCA & No longer valid & $\begin{array}{l}\text { Valid since } \\
\text { July 1999 }\end{array}$ & $\begin{array}{l}\text { Valid since } \\
\text { January 2010 }\end{array}$ & $\begin{array}{l}\text { Signed 1998, } \\
\text { not yet valid }\end{array}$ & $\begin{array}{l}\text { Valid since } \\
\text { July 1999 }\end{array}$ \\
\hline EPCA & $\begin{array}{l}\text { Valid since } \\
\text { March 2020 }\end{array}$ & $\begin{array}{l}\text { Negotiations } \\
\text { completed in } \\
2019\end{array}$ & $\begin{array}{l}\text { The Tajik side } \\
\text { requested } \\
\text { the opening of } \\
\text { negotiations } \\
\text { in November } \\
\text { 2018 }\end{array}$ & $\begin{array}{l}\text { Negotiations } \\
\text { started in } \\
\text { November 2018 }\end{array}$ \\
\hline
\end{tabular}

Source: Compiled by the authors based on European Commission data [2019].

The PCA with Turkmenistan was signed in 1998 but did not enter into force due to the political situation [Drienikova, 2018]. Bilateral relations between the EU and Turkmenistan are currently governed by an interim agreement on trade and trade-related matters, which entered into force in August 2010. The PCA is currently pending ratification by the European Parliament [EEAS, 2020]. Bilateral relations between the EU and Kazakhstan are governed by an EPCA signed on 21 December 2015 in Astana [Delegation of the European Union to Kazakhstan, 2018]. Most of the chapters of this agreement came into force on 1 May 2016, while the entire agreement came into force in March 2020. The economic part of the EPCA creates better regulation in areas such as trade in services, establishment of companies, capital movements, 
raw materials and energy, government procurement and intellectual property rights [EC, 2019]. To date, cooperation between Central Asia and Kazakhstan has been predominantly economically oriented, but in recent years we have also seen a deepening of social and cultural relations [Kembayev, 2016]. According to the EPCA, future cooperation between Kazakhstan and the EU focuses not only on economic issues but also on 29 other key areas including finance, energy, transport, education, culture and social issues.

\section{Analysis of Foreign Trade Relations Between the EU and Central Asia}

Central Asia is an important source of energy raw imports for the EU. The EU trade balance with Central Asia has been passive for a long time, which is due to the EU's dependence on imports of raw materials from these countries. Foreign trade between the EU and Central Asia has been relatively stable since the 2009 financial crisis. A decline in Central Asian imports into the EU was recorded in 2015 and 2016, caused mainly by a decline in oil prices. There was an increase in foreign trade in 2017-19. In 2019, the turnover between the EU and Central Asia reached 32.289 billion euros. The share of individual economies of Central Asia of foreign trade with the EU in 2019 was as follows: Kazakhstan, 85.1\%; Uzbekistan, 9.3\%; Turkmenistan, 3.3\%; Kyrgyzstan, 1.5\%; and Tajikistan, $0.8 \%$. The development of foreign trade between the EU and Central Asia is shown in Fig. 1.

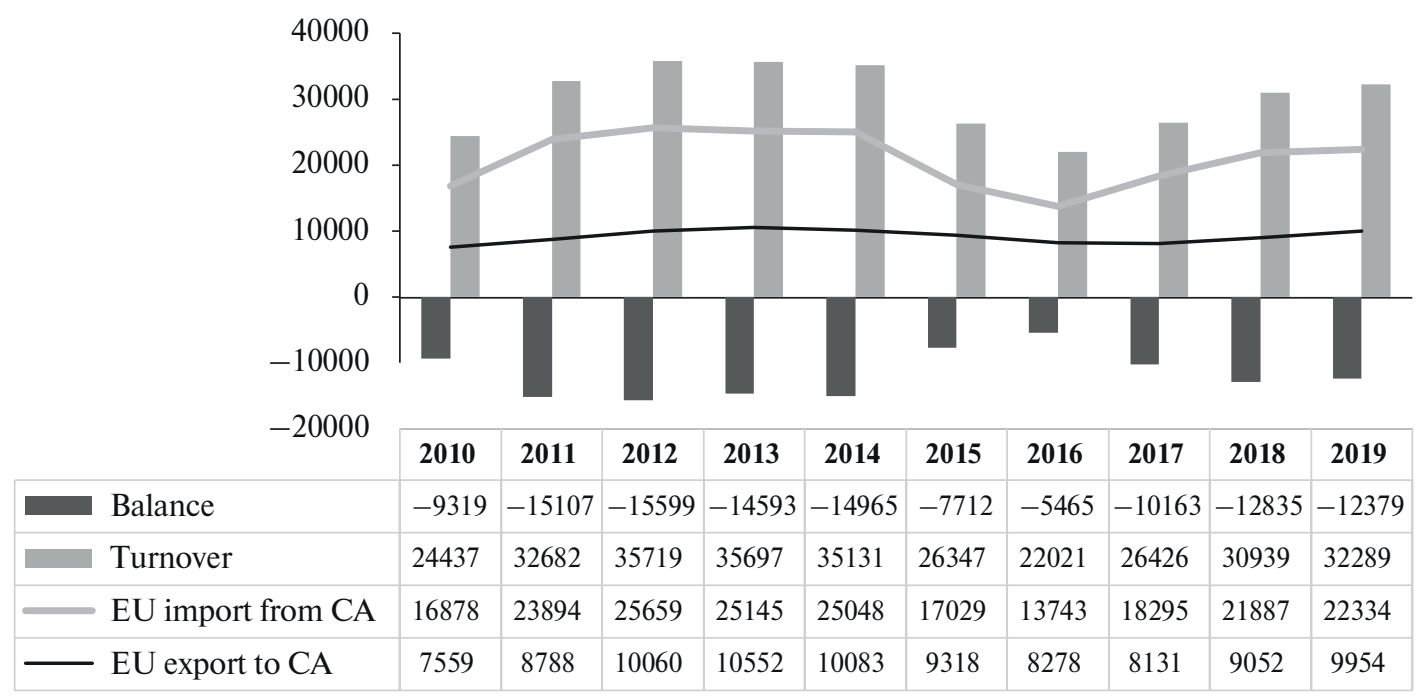

Fig. 1. Foreign Trade Between the EU and Central Asia (CA), 2010-19 (Million Euros)

Source: Compiled by the authors based on EUROSTAT data [n. d.].

According to SITC classification, in 2019 (Fig. 2) more than 90\% of Central Asian exports to the EU were mineral fuels, lubricants and related materials, followed by manufactured goods $(3.9 \%)$ and chemicals $(1.6 \%)$ [EUROSTAT, n. d.]. The EU supports the efforts of Central Asian countries to integrate into the world economy. As all five countries are mainly dependent on exports of unprocessed raw materials, the EU has set itself the objective of helping Central Asian countries diversify their exports through the generalized scheme of preferences (GSP) and the special incentive arrangement for sustainable development and good governance (GSP+), which provide reduced or zero tariffs for Central Asian exports to EU markets. 
Kyrgyzstan uses the GSP+ and Tajikistan and Uzbekistan use the GSP [EC, 2019]. The economic impact of the systems is not yet significant as, for example, in 2019 almost three quarters of Kyrgyz exports to the EU came from a single commodity, gold. In the future, this system could help products with export potential such as Kyrgyz dried fruit or Uzbek cotton to reach European markets.

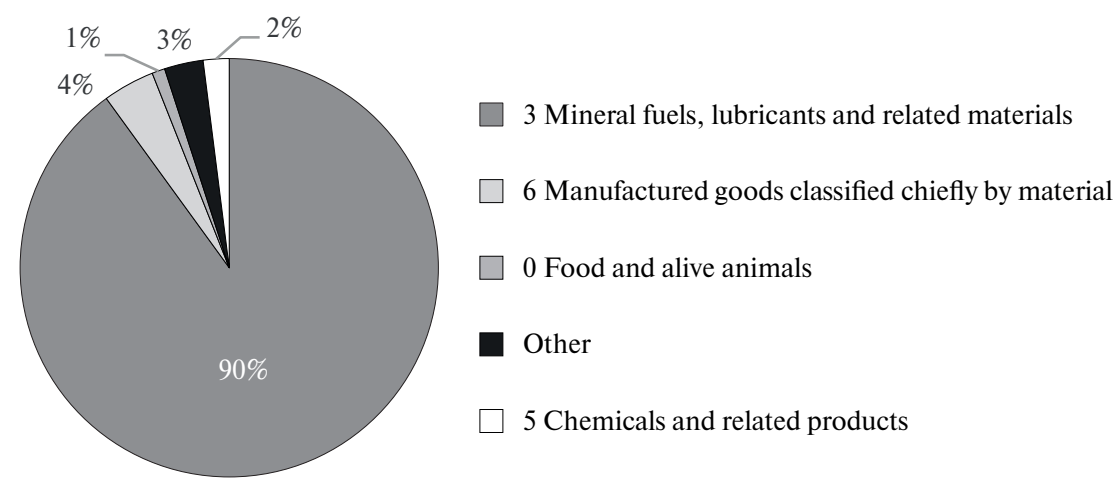

Fig. 2. SITC Commodity Structure of EU Imports From Central Asian Countries, 2019 (\% Share of Total Imports)

Source: Compiled by the authors based on EUROSTAT data [n. d.].

According to SITC classification, in 2019 (Fig. 3) more than 50\% of EU exports to Central Asia were machinery and transport equipment, followed by chemicals (18.4\%), miscellaneous manufactured articles (10.2\%), manufactured goods $(8.6 \%)$ and others (9\%). EU exports to Central Asia consist of more sophisticated products rather than raw materials.

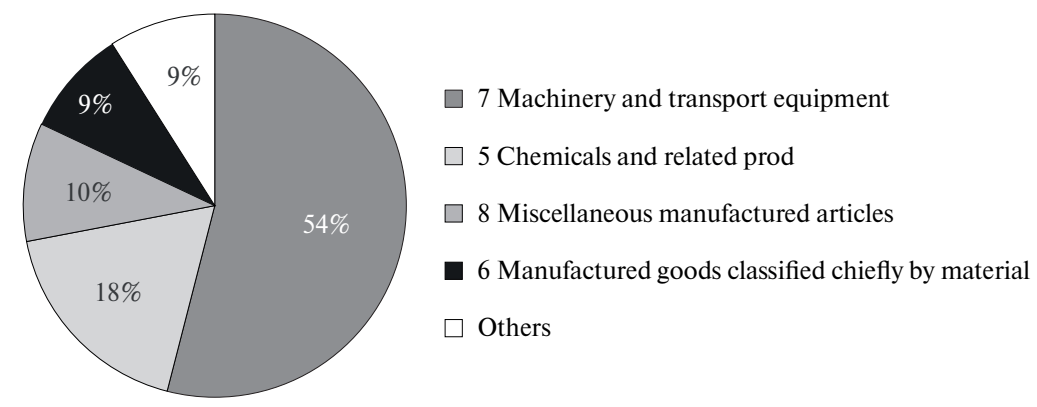

Fig. 3. SITC Commodity Structure of EU Exports to Central Asian Countries in 2019 (\% Share of Total Exports)

Source: Compiled by the authors based on EUROSTAT data [n. d.].

The EU is a major trading partner for Central Asia, with a share of more than $30 \%$ in Central Asia's foreign trade in 2019, followed by Russia and China (Fig. 4). On the other hand, Central Asia accounts for less than $1 \%$ of the EU's total external trade.

Based on this analysis, we conclude that the EU is a major trading partner for Central Asia and Central Asia's exports to the EU focus primarily on mineral and energy resources, as the EU takes first place in the importance of trading partners. 


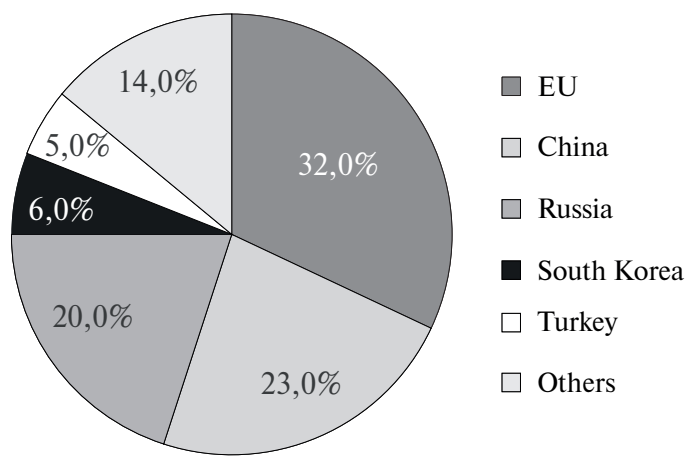

Fig. 4. Most Important Trading Partners of Central Asia, 2019 (\% Share of Total Trade)

Source: Compiled by the authors based on EUROSTAT data [n. d.].

\section{Potential of Bilateral Trade Relations Between the EU and Central Asia Based on Selected One-Factor Indices and Time-Series Prediction Model}

In addition to examining the current position of the Central Asian countries in the EU's external trade relations, it is necessary to determine how trade cooperation will develop and whether the trade cooperation between the EU and Central Asia has potential in the future. The nature and intensity of trade cooperation of the countries under review can be analyzed by calculating the trade complementarity index and the trade intensity index.

An analysis of the commodity structure of foreign trade between the EU and Central Asia provides an overview of the commodity groups that are the main subject of trade. EU exports to Central Asia are characterized by greater diversification than imports from Central Asia. Looking further to the direction of bilateral trade, it is important to consider the extent to which the demand and supply of the reviewed regions overlap. Such a view provides the trade complementarity index, the results of which are shown in Fig. 5.

The calculation of the TCI covers a longer period of time (2010-19). On the basis of the calculated values, it can be concluded that the EU is a very important market for Central Asia in terms of trade complementarity. The EU's supply overlaps with Central Asia's demand to a much higher extent than Central Asia's supply overlaps EU demand. With the EU's supply in Central Asia's demand, TCI has long been high, oscillating between 70 and 80 . The cause of high values is the increased demand from Central Asian countries for the sophisticated products of European companies. Regardless of the outcome of the TCI, this statement is also confirmed by the view of the commodity structure of EU exports to Central Asia. The main EU exports are of machinery, chemical products and transport equipment. The high diversification of EU exports to Central Asia also causes high TCI values in the EU's supply. The situation for Central Asia in the EU's demand is different. In the long term, TCI has been oscillating between 30 and 40. This shows a relatively low level of trade complementarity. The main reason for this situation is that, while the countries of Central Asia export mainly raw materials to the EU, the demand of Central Asian countries is focused primarily on more sophisticated products. Exports from Central Asia are poorly diversified, confirming the view of the commodity structure of EU imports from Central Asia. Based on the results of the TCI, it can be concluded that the EU is a significantly more important market for Central Asia than the Central Asian market is for the EU. However, the importance of Central Asia to the EU is, currently, particularly important in terms of the supply of mineral and energy resources. 


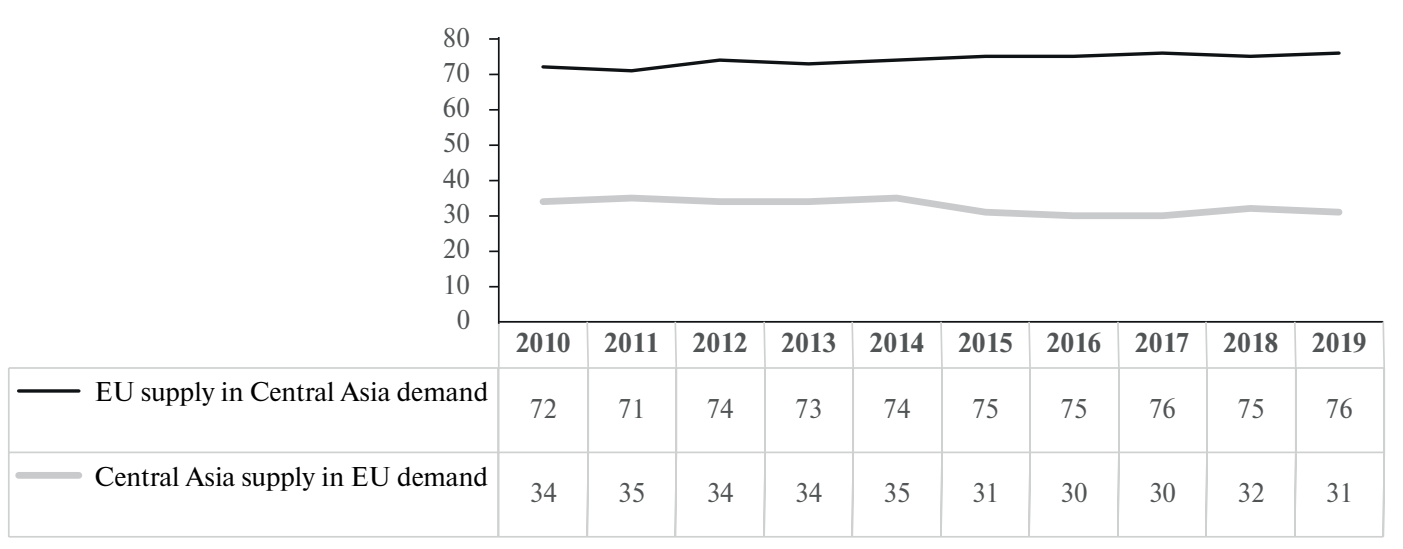

Fig. 5. Development of Trade Complementarity Between the EU and Central Asia Based on TCI, 2010-19

Source: Compiled by the authors based on UNCTADSTAT data [n. d.].

Trade intensity can also be used to evaluate foreign trade between the EU and Central Asia. The TII is used to evaluate whether trade volumes between two countries/regions are larger or smaller than would be expected based on their position in the world economy. A detailed overview of the EU-Central Asia TII 2010-19 is shown in Fig. 6.

Values of the EU-Central Asia trade intensity index for 2010-19 are below value 1, which means that trade volumes between them are smaller than expected by their position in the world economy. Central Asia is not an important trading partner for the EU, which is consistent with the fact that Central Asia accounts for less than $1 \%$ of the EU's foreign trade. The TII Central Asia-EU values are slightly higher than the TII EU-Central Asia, as the EU is an important trading partner for Central Asia.

In the examined period, the achieved values of the TII EU-Central Asia are in the range from 0.40 to 0.50 and the TII Central Asia-EU in the range from 0.58 to 0.83 and do not reach the required value of intensity. Nevertheless, we can state that in both cases a growth trend is observed, especially in the case of the TII Central Asia-EU.

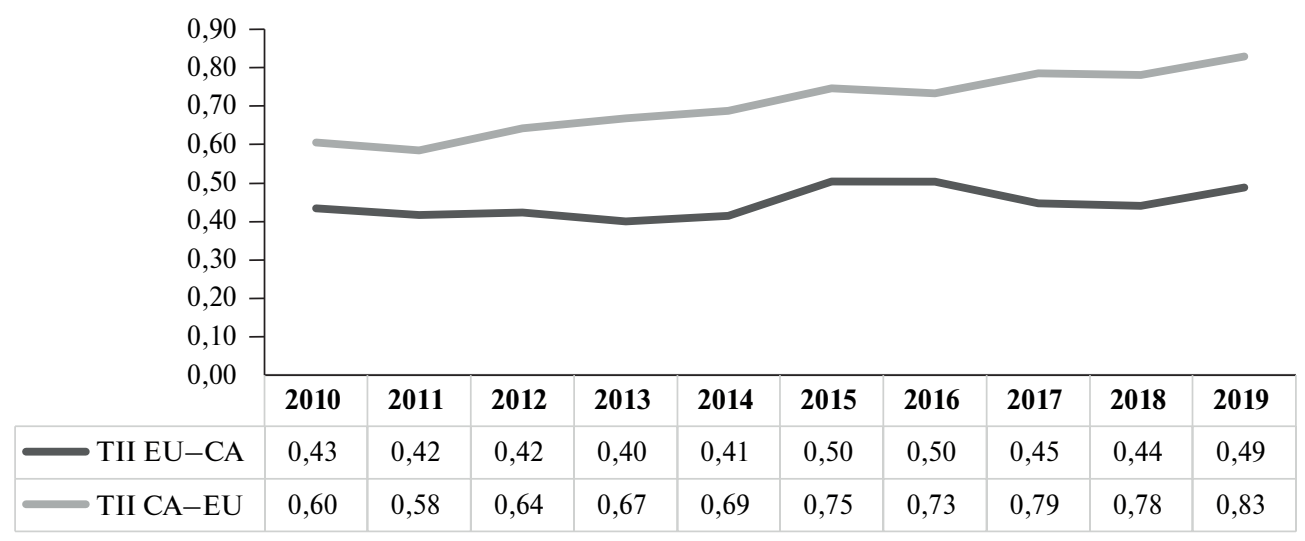

Fig. 6. Development of Trade Intensity Between the EU and Central Asia (CA) Based on TII, 2010-19

Source: Compiled by the authors based on UNCTADSTAT data [n. d.]. 
Indices of trade complementarity and intensity show that EU exports are more important to Central Asian countries than vice versa. At the same time, the indices point to the fact that the countries observed cannot be considered as important trading partners. However, mutual trade has been on the rise in recent years, partially thanks to bilateral initiatives to improve the contractual framework for trade relations. Most EU imports from Central Asian countries consist of minerals and fuels. We assume that this will also be the case in the long term, and thus the value of EU imports will be determined primarily by demand and prices of minerals. On the other hand, the structure of EU exports to Central Asian countries is much more diversified. The TCI points to the fact that demand for such production from Central Asian countries (regardless of other factors affecting international trade) exists. Thus, EU exports to Central Asian countries have growth potential in the future, as the three-year forecast model suggests in the following Fig. 7.

The forecasted development of EU exports to Central Asian countries is based on a time series of quarterly data since 2000. The recent development of exports tends toward growth in the long run. Based on these data, we expect that the main development trend will also be growth within the next three years. The red curve indicates the development of real exports and the green area indicates the area of $95 \%$ probability of export development. Based on our prediction for 2020-23, we expect that the value of EU exports will oscillate in the range of 1874.71 million euros to 3856.6 million euros. However, we must take into account a few factors that will have a strong influence on the development of EU exports. These factors are the development and implementation of the contractual basis, the competitiveness of EU production, economic development and vis major.

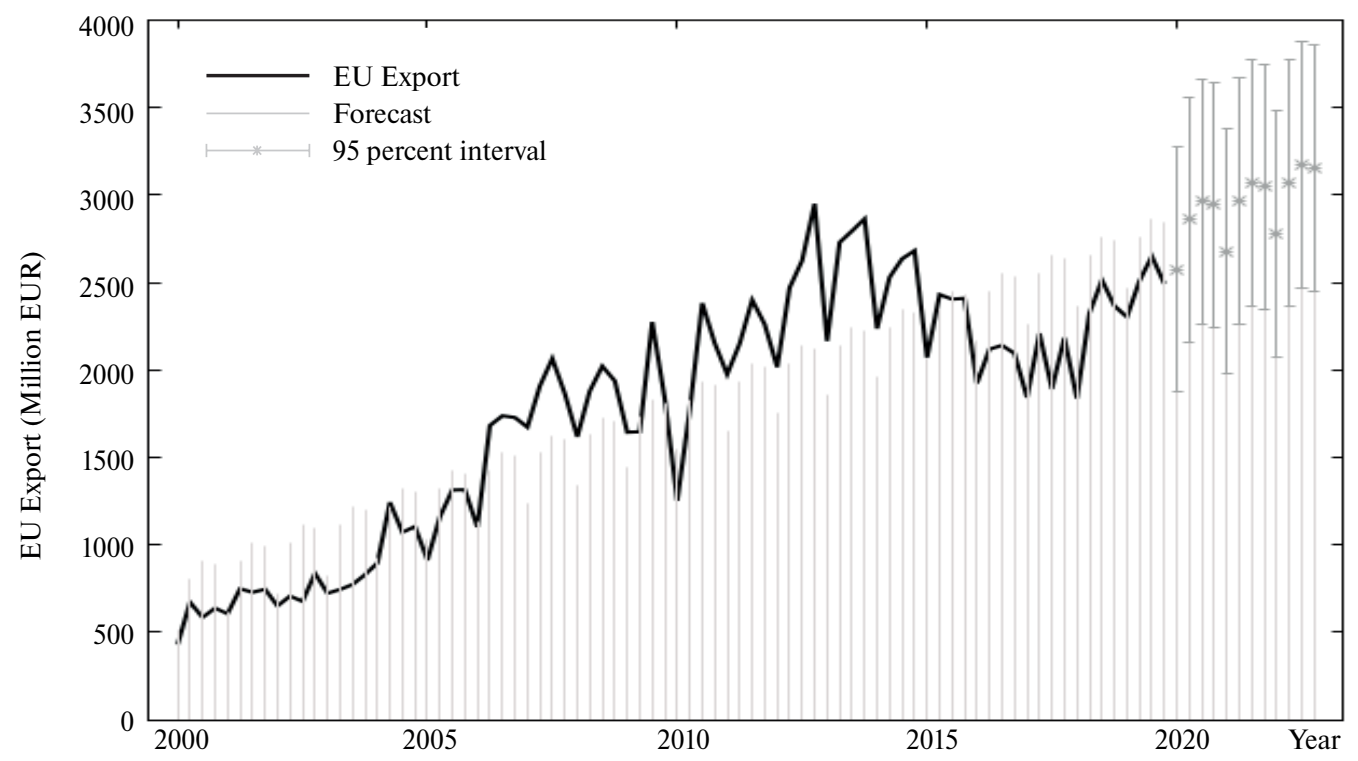

Fig. 7. Time-Series Prediction Model of EU Exports to Central Asia, 2020-23 (Million Euros)

Source: Compiled by the authors based on EUROSTAT data [n. d.].

Compared to the development of EU exports, the current development of EU imports from Central Asian countries has been significantly more turbulent and the average development trend is toward less growth. The sharp decline in imports in 2009 can be attributed to the 
impact of the global financial crisis. Fig. 3, which shows the commodity structure of EU imports from Central Asian countries, shows that a substantial part of imports consists of mineral fuels, namely oil and natural gas. Therefore, we assume that the value of this indicator has been significantly affected by changes in the prices of these commodities. At the turn of 2008 and 2009, as well as in 2014, there was a sharp drop in oil prices, which is clearly reflected in the value of EU imports. When creating the forecast, we must state that EU imports from Central Asian countries will continue to be strongly dependent on the development of mineral fuel prices. Based on the observations since 2002, we can expect a trend of slightly increasing EU imports. Working with a $95 \%$ probability interval, we expect that the value of exports in the next three years will oscillate in the range of 3153.4 million euros to 8931.4 million euros. However, due to the current exceptional situation caused by the COVID-19 pandemic, which has caused oil prices to fall to historic lows, it may not be surprising that the value of EU imports will fall below our predicted values. It will therefore be important how long this pandemic lasts.

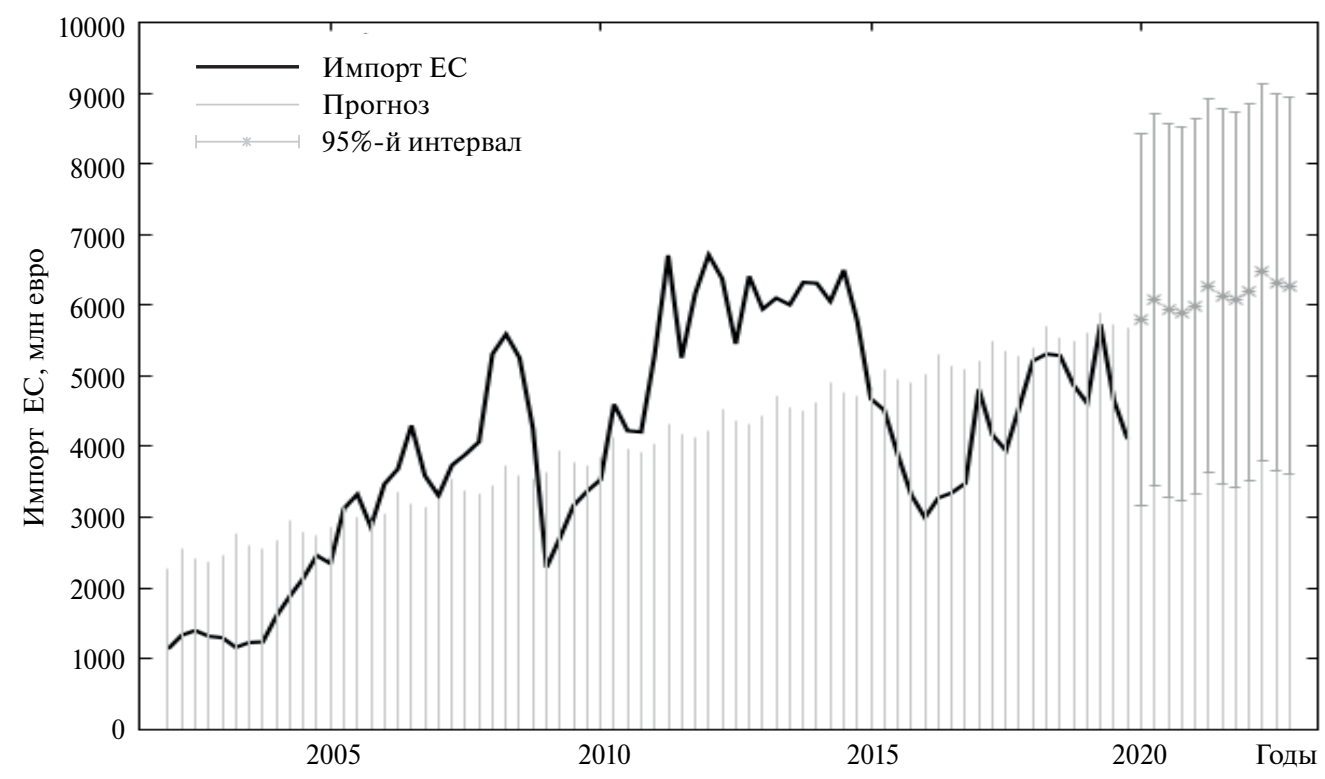

Fig. 8. Time-Series Prediction Model of EU Imports From Central Asia, 2020-23 (Million Euros)

Source: Compiled by the authors based on EUROSTAT data [n. d.].

\section{Conclusions}

Based on analysis of the EU's foreign trade relations with Central Asia and the determination of possible perspectives for the further development of their mutual trade relations in the context of geoeconomic change, we offer the following conclusions.

In June 2019, the EU developed and adopted a new strategy - The EU and Central Asia: New Opportunities for a Stronger Partnership - which focuses on areas such as water and environmental cooperation, socio-economic development, support for SMEs and support for regional trade. The EU's bilateral relations with the countries of Central Asia are governed by non-preferential partnership and cooperation agreements.

Central Asia is an important source of energy raw materials for the EU. The EU's trade balance with the countries of Central Asia has been negative for a long time due to the EU's 
dependence on imports of energy raw materials from these countries. At the same time, we can state that the EU is the most important trading partner for Central Asia.

Based on time series until 2023, EU exports to Central Asian countries are forecasted to grow, although their development will be influenced by several factors, such as the implementation of the contractual basis, the competitiveness of EU production, and the impact of the pandemic on the economic development of the EU. Successful implementation and further development of the contractual basis, at both the individual and supranational level, will be important for the favourable development of mutual trade between the examined countries. This process is, however, going to take longer than three years. Nevertheless, the favourable development of negotiations can have a positive impact on the development of EU exports in the short term. If European producers want to be competitive in the markets of Central Asian countries, they must be able to offer sophisticated products which meet the needs of local demand. The price competitiveness will be important as well. China has incorporated these countries into its New Silk Road initiative, strengthening its position in both commercial and political terms. Serious competition comes from producers in Russia, with which Central Asian countries have historical ties.

The current COVID-19 pandemic brings a considerable degree of uncertainty to the future development of trade relations, not only of the observed countries but also of the global economy. The duration of this exceptional situation, which is already having serious consequences for EU economies, is difficult to predict. Therefore, in the event of a deterioration of the situation, a decrease in the value of EU exports as well as imports even below the modelled probability cannot be ruled out.

\section{References}

Apokins I. (2016). Reviewing the EU Strategy for Central Asia: Results and Future Prospects. L'Europe en Formation, vol. 2015/1, no 375, pp. 10-7. Available at: https://doi.org/10.3917/eufor.375.0010.

Baláž P., Královičová M., Steinhauser D. (2020). Foreign Trade as a Tool to Strengthen the EU's Competitiveness Against China (A Case of the Service Sector). Prague Economic Papers, vol. 29, no 2, pp. 129-51. Available at: https://doi.org/10.18267/j.pep.731.

Boonstra J., Panella R. (2018). Three Reasons Why the EU Matters to Central Asia. Available at: http://voicesoncentralasia.org/three-reasons-why-the-eumatters-to-central-asia/

Brown A.J. (1949). Applied economics\&aspects of world economy in war and peace. The Journal of Economics History, roč. 5, no1.

Byrd W., Raiser M., Dobronogov A., Kitain A. (2006). Economic Cooperation in the Wider Central Asia Region. World Bank Working Paper no 75. Available at: https://openknowledge.worldbank.org/handle/10986/6969 (accessed 18 February 2021).

Cornell S.E., Engvall J. (2017). The EU and Central Asia: Expanding Economic Cooperation, Trade and Investment. The Central Asia-Caucasus Analyst, 6 September. Available at: https://www.cacianalyst.org/publications/feature-articles/item/13465-the- (accessed 18 February 2021).

Delegation of the European Union to Kazakhstan (2018). Kazakhstan and the EU. Available at: https://eeas. europa.eu/delegations/kazakhstan_en/1367/Kazakhstan\%20and\%20the\%20EU

Drieniková K. (2018). Špecifiká zahraničnoobchodnej politiky EÚ voči Strednej Ázii [The Specifics of EU Trade Policy Toward Central Asia]. Vedecké state obchodnej fakulty 2018/1. Bratislava: Ekonóm.

Drysdale P., Garnaut R. (1982). Trade intensities and the analysis bilateral trade flows in a many country world: survey. Hitotsubashi Journal of Economics, roč. 22, no 2.

Euractiv (2019). The New EU Strategy for Central Asia. 18 June. Available at: https://www.euractiv.com/section/central-asia/infographic/the-new-eu-strategy-for-central-asia/ (accessed 18 February 2021). 
European Commission (EC) (2019). A Renewed Partnership With Central Asia. Available at: https://ec.europa. eu/commission/news/renewed-partnership-central-asia-2019-may-15_en.

European External Action Service (EEAS) (2020). EU-Turkmenistan Relations. EEAS Fact Sheet, 17 November. Available at: https://eeas.europa.eu/regions/central-asia/4077/eu-turkmenistan-relations_en (accessed 18 February 2020).

EUROSTAT (n. d.). International Trade in Goods Database. Available at: https://ec.europa.eu/eurostat/web/ international-trade-in-goods/data/database (accessed 18 February 2021).

Fida Z. (2018). Central Asia's Place in Turkey's Foreign Policy. Policy Perspectives, vol. 15, no 1, pp. 113-25. Available at: https://www.jstor.org/stable/10.13169/polipers.15.1.0113.

Gast A.-S. (2014). A Shift in the EU Strategy for Central Asia? Carnegie Moscow Center, 30 April. Available at: http://carnegie.ru/publications/?fa=55483 (accessed 18 February 2021).

Gnidchenko A. (2018). Mnogopolyarnoe zamedlenie i ozhivlenie mirovoy torgovli [Multipolar Global Trade Slowdown and Revival]. HSE Economic Journal, vol. 22, no 4, pp. 583-608 (in Russian).

Grieger G. (2015). The Shanghai Cooperation Organisation. Available at: https://www.europarl.europa.eu/ thinktank/en/document.html?reference=EPRS_BRI(2015)564368

Iqbal M., Afridi M.K. (2017). New Great Game in Central Asia: Conflicts, Interests and Strategies of Russia, China and United States. The Dialogue, vol. 12, no 3, pp. 229-46. Available at: https://www.qurtuba.edu. pk/thedialogue/The\%20Dialogue/12_3/Dialogue_July_September2017_229-246.pdf (accessed 18 February 2021).

Kembayev Z. (2016). Partnership Between the European Union and the Republic of Kazakhstan: Problems and Perspectives. European Foreign Affairs Review, vol. 21, no 2, pp. 185-203. Available at: https://ssrn.com/ abstract=2889952 (accessed 18 February 2021).

Kojima K. (1964). The pattern of international trade among advanced countries. Hitotsubashi Journal of Economics, roč. 11, no 2 .

Konopelko A. (2018). Eurasian Economic Union: A Challenge for EU Policy Towards Kazakhstan. Asia Europe Journal, vol. 16, no 1, pp. 1-17. Available at: https://doi.org/10.1007/s10308-017-0480-7.

Lukáčiková A., Lukáčik M., Szomolányi K. (2018). Úvod do ekonometrie s programom Gretl [Introduction to Econometrics with the Gretl Programme]. Bratislava: Letra Edu (in Slovak).

Makarenko T. (2009). Stredná Ázia - oblast', kde sa kríži moc, politika a ekonomika [Central Asia - An Area Where Power, Politics and the Economy Intersect]. NATO Review. Available at: http://www.nato.int/docu/ review/2009/Asia/central_asian_geopolitics/SK/index.htm (accessed 18 February 2021) (in Slovak).

Makarenko T. (2009). Central Asia - An Area Where Power, Politics and the Economy Intersect. NATO Review. Available at: http://www.nato.int/docu/review/2009/Asia/central_asian_geopolitics/SK/index.htm

Michaely M. (1996). Trade Preferential Agreements in Latin America: An Ex Ante Assessment. Policy Research Working Paper no 1583. World Bank. Available at: http://documents1.worldbank.org/curated/ en/934301468773398976/pdf/multi0page.pdf (accessed 18 February 2021).

Prokhorov A. (1975). Great Soviet Encyclopedia. New York: Macmillan.

Puškárová P. (2015). Assessing the Magnitude of Globalization-Induced Technology Flows in Expanded EUSample: A Multi-Channel Approach. Procedia Economics and Finance, vol. 20, pp. 544-52. Available at: https://doi.org/10.1016/S2212-5671(15)00107-0.

Ružeková V., Kittová Z., Steinhauser D. (2020). Export Performance as a Measurement of Competitiveness. Journal of Competitiveness, vol. 12, no 1, pp. 145-60. Available at: https://doi.org/10.7441/joc.2020.01.09.

Teleuova S.A. (2015). Some Aspects of the European Union's Policy towards Central Asia. In Asian Social Science, vol. 11, č. 14, s. 219-227.

United Nations Conference on Trade and Development Database (UNCTADSTAT) (n. d.). Available at: https://unctadstat.unctad.org/EN/.

World Bank (2010). Trade Indicators. Available at: https://wits.worldbank.org/wits/wits/witshelp/Content/ Utilities/e1.trade_indicators.htm 
World Bank (2013). Online Trade Outcome Indicators. Available at: http://wits.worldbank.org/WITS/docs/ TradeOutcomes-UserManual.pdf

World Bank (2019). The World Bank in Central Asia. [online]. Available at: http://www.worldbank.org/en/ region/eca/brief/central-asia

World Bank (2019). The World Bank in Central Asia. [online]. Available at: http://www.worldbank.org/en/region/eca/brief/central-asia

WTO (2012). A practical guide to trade policy analysis. Ženeva: WTO.

Yamazawa I. (1971). Structural changes in world trade flows. Hitotsubashi Journal of Economics, 21971, roč. 11, no 2 . 